\title{
Bioethica
}

Vol 7, No 2 (2021)

Bioethica

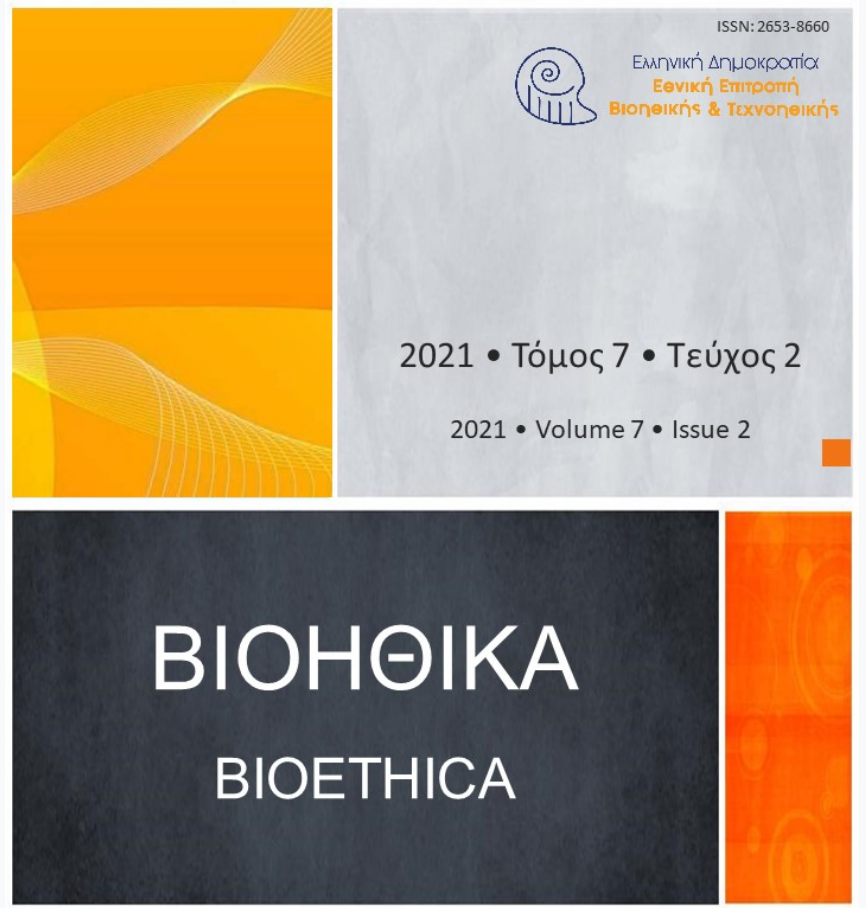

Review of the current and post-Brexit UK legal framework on the regulation of genetic technologies

Adiba Firmansyah

doi: $10.12681 /$ bioeth.28152

Copyright ( $)$ 2021, Adiba Firmansyah

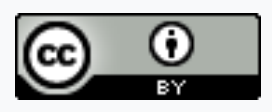

This work is licensed under a Creative Commons Attribution 4.0.

To cite this article:

Firmansyah, A. (2021). Review of the current and post-Brexit UK legal framework on the regulation of genetic technologies. Bioethica, 7(2), 51-68. https://doi.org/10.12681/bioeth.28152 


\title{
Avaбкórnon
}

\section{Review of the current and post-Brexit UK legal framework on the regulation of genetic technologies}

\section{Adiba Firmansyah}

Stagiaire, National Commission for Bioethics \& Technoethics

adibarahmah@gmail.com

\begin{abstract}
The launch of a nationwide consultation in January 2021 by the UK Department for the Environment, Food and Rural Affairs (Defra) on the regulation of genetic technologies has been used as an opportunity by the UK Government to gauge public and scientific opinion on the applications of gene editing in agriculture and aquaculture. In particular, the consultation sought to consider the controversial question of whether gene editing (GE) should be subject to the same regulations as genetically modified organisms (GMOs). The distinction between GE and GMO products, as well as between the legal regulations governing them, are highly important: currently, the UK still follows the EU's restrictive approach, whereby gene editing is regulated in the same way as GMOs. However, in light of the UK's departure from the EU, the UK government seems willing to reconsider this approach and adopt a new regulatory framework characterised by less stringent controls. Accordingly, this review paper examines the current legal framework on gene editing and GMOs in the UK and EU, as well as in other relevant jurisdictions, before then examining the Defra consultation in light of the mixed responses to it from both the scientific community and the general public. The paper concludes with a number of considerations that should inform any proposed post-Brexit reform of the framework that allows for the correct balance to be struck between scientific development, food security, human health, and the environment.
\end{abstract}

Keywords: bioethics, GMOs, gene editing, agriculture, UK. 


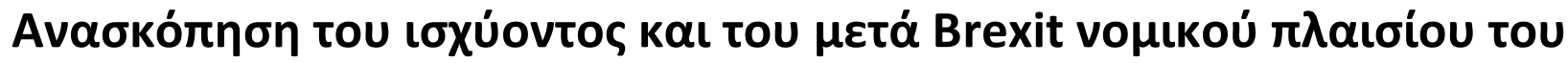

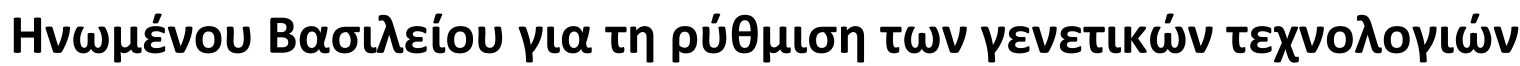

\section{Adiba Firmansyah}

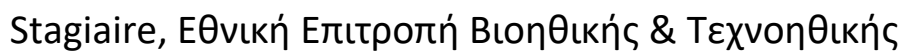

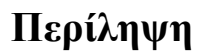

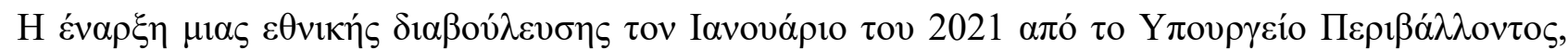

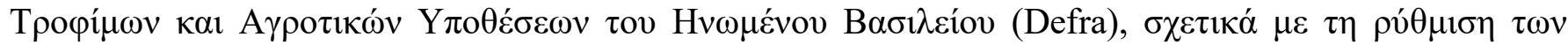

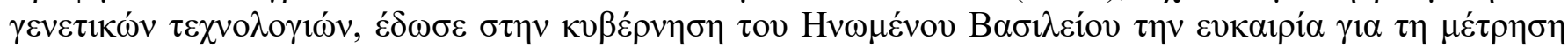

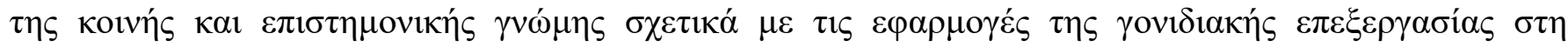

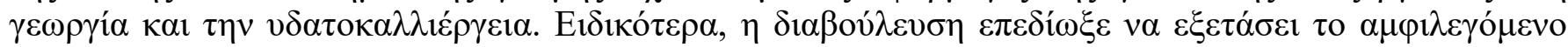

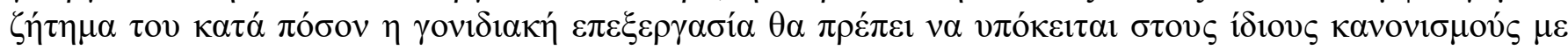

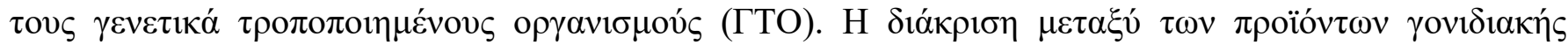

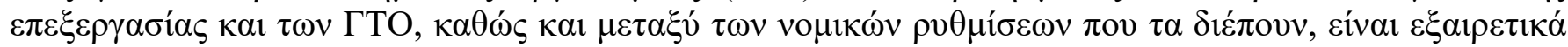

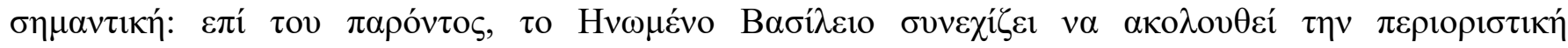

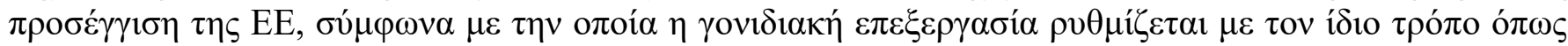

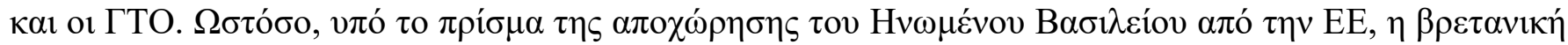

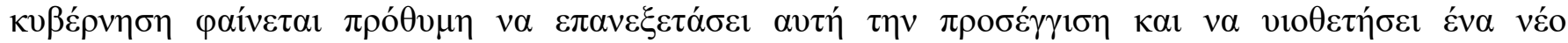

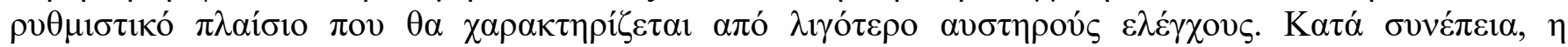

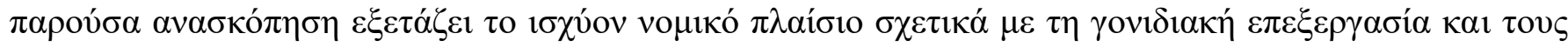

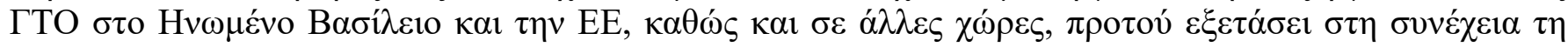

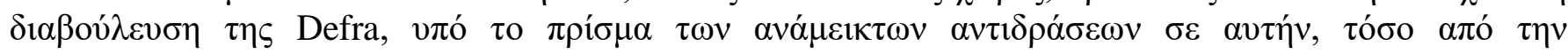

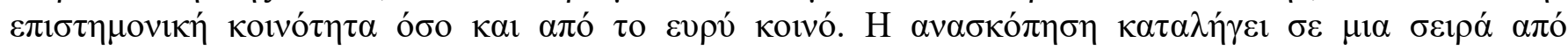

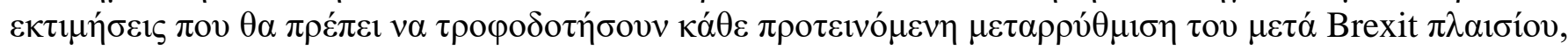

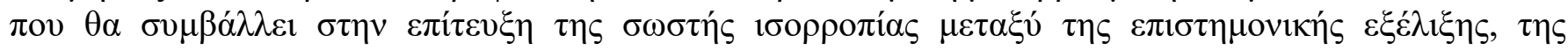

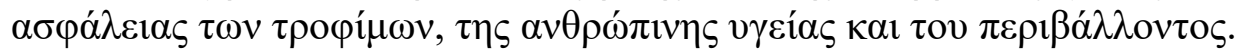

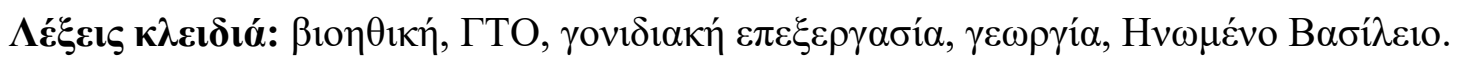




\section{A. Introduction}

In January 2021, the UK Department for the Environment, Food and Rural Affairs (Defra) launched a consultation on the regulation of genetic technologies, and in particular, on the applications of gene editing in agriculture and aquaculture. ${ }^{1}$ To that end, the Defra consultation will consider the controversial question of whether gene editing (GE) should be subject to the same regulations as genetically modified organisms (GMOs). ${ }^{2}$ In this respect, it is important to note that gene editing is different from genetic modification, which involves DNA from one species being introduced to another. ${ }^{3}$ In contrast, gene edited organisms do not contain DNA from different species, and instead involve the use of technologies, such as CRISPR (e.g., clustered regularly interspaced short palindromic repeats/Cas9) that produce quicker and more precise changes to organisms that would have occurred naturally - but far more slowly - over time using traditional breeding methods. ${ }^{4}$

At the moment the UK still follows the European Union's approach, whereby gene editing is regulated in the same way as GMOs. ${ }^{5}$ However, in light of the UK leaving the EU, the UK Government seems willing to adopt a new

${ }^{1}$ UK Department for the Environment, Food and Rural Affairs. The regulation of genetic technologies. 2021. https://consult.defra.gov.uk/agri-food-chaindirectorate/the-regulation-of-genetic-technologies/ accessed 29 March 2021.

${ }^{2}$ Ibidem.

3 UK Department for the Environment, Food and Rural Affairs. Gene editing: explainer. 2021. https://consult.defra.gov.uk/agri-food-chain-

directorate/the-regulation-of-genetic-

technologies/supporting_documents/Gene\%20Editin g\%20Explainer.pdf accessed 29 March 2021.

${ }^{4}$ Ibidem.

5 Defra, The regulation of genetic technologies, op.cit. regulatory framework on gene editing: one that is subject to less strict controls and that has the potential, as the Government sees it, to 'breed crops that perform better, reduc[e]costs to farmers and impacts on the environment and help us all adapt to the challenges of climate change'. ${ }^{6}$ Yet others have argued that the possible harm to human health from scientific intervention at the genetic level and from reduced safeguards is too high a risk to accept. ${ }^{7}$

This review paper will first set out the current legal framework on gene editing and GMOs in the UK and EU, as well as in other relevant jurisdictions, before then examining the Defra consultation in light of the responses to it that have been both positive and critical. The paper concludes with a number of considerations that should inform any proposed reform of the framework post-Brexit and that allows for the correct balance to be struck between scientific development, food security, human health, and the environment.

\section{B. The legal framework on gene edited and genetically modified crops: a global overview}

Over the last two years alone, 26 countries grew approximately 190 million hectares of GM crops. ${ }^{8}$ Of these 26 countries, 21 are developing countries and five are industrial countries. ${ }^{9}$

\footnotetext{
${ }^{6}$ Sandercock H. Defra launches consultation on crop gene editing plans. The Grocer 2021. https://www.thegrocer.co.uk/fruit-and-veg/defralaunches-consultation-on-crop-gene-editingplans/651858.article accessed 29 March 2021.

${ }^{7}$ Marshall C. Consultation launched over gene edited food in England. BBC 2021. https://www.bbc.com/news/science-environment55576187 accessed 29 March 2021.

${ }_{8}^{8}$ Turnbull C, et al. Global Regulation of Genetically Modified Crops Amid the Gene Edited Crop Boom A Review. Frontiers in Plant Science 2021: 12.

${ }^{9}$ Ibidem.
} 
Industrial countries include the United States, Australia, and Canada, growing around $46 \%$ of total GM crops. ${ }^{10}$ The developing countries growing $54 \%$ of the total include India, Brazil and Argentina. ${ }^{11}$ Against this background, it is important to examine the regulatory framework of these countries that enables cultivation of GM crops on such a large scale.

Governments around the world will generally seek to create a regulatory framework that provides the necessary safeguards for their citizens and for the environment. ${ }^{12}$ In a similar vein, the laws applying to agriculture and aquaculture destined for consumption will seek to protect these human and environmental interests. Yet the way this is implemented will differ between countries and regions. Broadly speaking, GM regulations are usually categorised into process- or product-oriented regulations. ${ }^{13}$ Process-oriented regulations categorise GM technologies as a novel technique compared to traditional breeding methods, thereby triggering specific legislation to be applied. ${ }^{14}$ These types of GM regulations ensure that in the event genetic technologies and engineering are used, there are some checks on whether any errors have been introduced during the process of engineering before the crop or animal is farmed and/or eaten. ${ }^{15}$ Accordingly, process-oriented

${ }^{10}$ International Service for the Acquisition of Agribiotech Applications (ISAAA). GM Approval Database

http://www.isaaa.org/gmapprovaldatabase/default.asp accessed 29 March 2021.

${ }^{11}$ Ibidem.

${ }^{12}$ Turnbull, op cit.: 3 .

${ }^{13}$ Sprink $\mathrm{T}$, et al. Regulatory hurdles for genome editing: process-vs. product-based approaches in different regulatory contexts. Plant Cell Reports 2016, 35: 7.

${ }^{14}$ Ibidem.

15 Sam C. New developments in modern biotechnology: A survey and analysis of the regulations emphasises that how an organism is produced is relevant. ${ }^{16}$ Proponents of this approach highlight that direct intervention at the genetic level differs from traditional breeding methods and that this may lead to unexpected errors across the genome and that may pose a threat to humans or the environment. ${ }^{17}$

Product-oriented regulations, on the other hand, emphasise the novel characteristics of the product compared to those produced by traditional breeding methods. ${ }^{18} \mathrm{~A}$ move to product-based regulations, therefore, means that regulators will no longer be required to consider how a plant or animal was created. ${ }^{19}$ This lack of oversight has been criticised for the potential risk stemming from unexpected results, such as new allergens or toxins, that may go unnoticed, if there are no checks on the processes used by scientists and genetic engineers. ${ }^{20}$ Consequently, it has been argued that consumers may then be forced to simply take their word for it that these scientists have only made the DNA changes planned and declared. ${ }^{21}$ At this point, Canada is the only country in the world that has based their

regulatory status of plants produced through New Breeding techniques. https://lib.ugent.be/fulltxt/RUG01/002/213/647/RUG $\underline{01-002213647 \quad 20150001 \quad \text { AC.pdf }}$ accessed 29 March 2021.

${ }^{16}$ GM Freeze. GM Freeze advice on responding to the UK consultation on the deregulation of gene editing. January 2021. https://www.gmfreeze.org/wpcontent/uploads/2021/01/GMF-Gene-Editing-

Consultation-1-2.pdf accessed 29 March 2021.

${ }^{17}$ Idem: 5.

${ }^{18}$ McHughen A. A critical assessment of regulatory triggers for products of biotechnology: product vs. process. GM Crops Food 2016: 7.

${ }^{19}$ GM Freeze, op cit.: 16.

${ }^{20}$ Ibidem.

${ }^{21}$ Ibidem. 
entire GM regulatory framework on the productoriented approach. ${ }^{22}$

Discussions on the regulation of gene edited organisms have, therefore, mainly centered on which of the two approaches is best. ${ }^{23}$ Research by Eckerstorfer concluded that both systems have their advantages and disadvantages and neither system can be said to be better than the other. ${ }^{24}$ While there is no broad consensus yet, biotechnology scientists globally seem to be in favour of the product-based approach, as it has been deemed to be a more 'scientifically-friendly' approach. ${ }^{25}$ Indeed, McHughen has noted that scientific assessments should form the basis of effective risk management, and that regulations rely heavily on risk management to protect human health and the environment. $^{26}$ However, as Turnbull emphasises, even as science must shape regulatory frameworks, this cannot and does not occur in isolation. ${ }^{27}$

\section{The restrictive approach to regulating biotech}

As the point of departure in discussing the potential reforms to the UK regulatory framework on gene edited organisms, it is

\footnotetext{
${ }^{22}$ Ellens K, et al. Canadian regulatory aspects of gene editing technologies. Transgenic Research 2019, 28 : 2.

${ }^{23}$ Sprink, op cit.: 1493-1506.

${ }^{24}$ Eckerstorfer MF, Engelhard M, Heissenberger A, Simon S, Teichmann H. Plants developed by new genetic modification techniques - comparison of existing regulatory frameworks in the EU and NonEU countries. Frontiers of Bioengineering and Biotechnology 2018, 7: 26.

${ }^{25}$ Turnbull, op cit.: 3 .

${ }^{26} \mathrm{McHughen} \mathrm{A.} \mathrm{A} \mathrm{critical} \mathrm{assessment} \mathrm{of} \mathrm{regulatory}$ triggers for products of biotechnology: product vs. process. GM Crops Food 2016: 7.

${ }^{27}$ Turnbull, op cit.: 3 .
}

necessary to start with the approach of the EU, which the UK currently retains.

\section{European Union}

In the EU, Regulation (EC) No 1829/2003 on genetically modified food and feed binds all 27 Member States and covers GM food and feed produced 'from' a GMO, including food and feed products and their imports. ${ }^{28}$ Prioritising a high level of protection to human, animal and environmental health, ${ }^{29}$ the Regulation governs the authorisation procedures related to GM organisms and is applied in conjunction with Regulation 1830/2003 on the tracing and labelling of GM products. ${ }^{30}$ However, in relation to the cultivation of GM crops, Member States may choose their own approach under Directive 2001/18/EC on the deliberate release into the environment of genetically modified organisms (referred to as the 'Cultivation Directive'). This Directive provides for the cultivation of GM crops only once there has been a rigorous assessment of potential negative impacts on human health and the environment. ${ }^{31}$

Under the Cultivation Directive, Member States are allowed to 'provisionally restrict or prohibit the use and/or sale of that GMO as or in a product on its territory'. ${ }^{32}$ Once the European Food Safety Authority (EFSA) approves a particular crop for cultivation, Article 23 of the Directive allows Member States to restrict or prohibit that GM crop from cultivation in their territory. Since the inclusion of this clause into the Directive, a number of EU Member States

\footnotetext{
28 Paragraph 16 of the Preamble to the Regulation (EC) No 1829/2003.

${ }^{29}$ Article 1 of Regulation 1829/2003.

${ }^{30}$ Regulation (EC) No $1830 / 2003$ on the traceability and labeling of genetically modified organisms (GMOs) and the traceability of food and feed products produced from GMOs.

${ }^{31}$ Article 2(8) of Directive 2001/18/EC.

${ }^{32}$ Article 23(1) of Directive 2001/18/EC.
} 
have imposed a de facto ban on the cultivation of GM crops, including France and Germany. ${ }^{33}$

The EU's approach to defining a 'genetically modified organism' is often pointed to as a prime example of a process-triggered regulatory framework. ${ }^{34}$ Article 2(2) of the Cultivation Directive states that an organism is genetically modified if the alteration of genetic material is carried out in a way that is not natural mating and/or recombination. Notably, this definition is consistent with the concepts and terminology of international treaties such as the Cartagena Protocol on Biosafety to the Convention on Biological Diversity. ${ }^{35}$ In its landmark ruling in 2018, the European Court of Justice (ECJ) interpreted this provision to mean that organisms altered through site-directed metagenesis (the formation of mutations in DNA molecules), such as through CRISPR/Cas9, were to be included in the definition of a GMO. ${ }^{36}$ The implications of this judgment are that the size or type of modification to the genetic material becomes irrelevant. As Wasmer notes, if there is

${ }^{33}$ Lombardo L, Grando MS. Genetically modified plants for nutritionally improved food: a promise kept?. Food Reviews International 2020: 36.

34 Marchant GE, Stevens YA. A new window of opportunity to reject process-based biotechnology regulation. GM Crops Food 2015: 6.

35 Bendiek J, Buhk H. Risk Assessment and Economic Applications - the Cartagena Protocol on Biosafety: GMO Approval and Import on a WorldWide Scale. In: Kempken F, Jung C (eds). Genetic Modification of Plants. Springer, 2010: 631.

${ }^{36}$ Judgment of the Court (Grand Chamber), 25 July 2018 in Case C-528/16 Confédération paysanne and Others v Premier ministre and Ministre de l'Agriculture, de l'Agroalimentaire et de la Forêt http://curia.europa.eu/juris/document/document.jsf;js essionid=9ea7d0f130dcd5adc6577ba74dc9b5acf2530 b87e485.e34KaxiLc3eQc40LaxqMbN4Pb3yRe0text $=\&$ docid $=204387 \&$ pageIndex $=0 \&$ doclang=EN\&mod e=req\&dir $=$ accessed 29 March 2021. mutagenesis, whether random or controlled, big or small, the organism will be legally categorised as a GMO ${ }^{37}$ Accordingly, the ECJ clarified that this rule should be the starting point for the determination of what constitutes a GMO. ${ }^{38}$ However, it also highlighted that there are exceptions to this strict approach in the accompanying exceptions to the Cultivation Directive, and that these are only included based on their long safety record. ${ }^{39}$

Indeed, EU law on GM food covers most modified plant products, aside from those created by the exempted techniques. ${ }^{40}$ Such techniques include those involving mutation breeding based on techniques used before the Directive came into force in 2001, but not any of the newer forms of mutagenesis. ${ }^{41}$ This inconsistency means that, as a result, the ECJ's decision has been heavily criticised as being arbitrary and accusations that the regulations are no longer fit for purpose. ${ }^{42}$ However, the ECJ decision did prompt the Council of the European Union to request a study on the status of "new

37 Wasmer M. Roads forward for European GMO policy-uncertainties in wake of ECJ judgment have to be mitigated by regulatory reform. Frontiers of Bioengineering and Biotechnology 2019, 7: 132

${ }^{38}$ ECJ, 2018, op cit.: paras. 44-46.

${ }^{39}$ Exempted techniqes are listed in Annex I A Part 2 and Annex I B of Directive 2001/18/EC.

${ }^{40}$ Eriksson D, Custers R, Edvardsson Björnberg K, Hansson SO, Purnhagen K, Qaim M. Options to reform the European Union legislation on GMOs: scope and definitions. Trends in Biotechnology 2020, 38: 231-234.

41 Wanner B, Monconduit H, Mertens A, and Thomaier J. CJEU renders decision on the interpretation of the GMO Directive. Journal of Intellectual Property Law and Practice 2019: 14.

${ }^{42}$ Smyth S. Canadian regulatory perspectives on genome engineered crops' GM Crops \& Food 2017, 8: 1 . 
genomic techniques'. ${ }^{43}$ This seems to be a positive step, as the concrete evidence collected will underpin and inform any potential reform of EU law.

\section{United Kingdom}

As the UK Government highlighted in its announcement of the Defra consultation, EU law controlling the use of GMOs was retained by the UK at the end of the Brexit transition period (after 31 December 2020). ${ }^{44}$ This retained legislation mandates all gene edited organisms to be classified as GMOs regardless of whether they could be produced by traditional breeding methods, in line with the 2018 ECJ ruling. ${ }^{45}$

In terms of the governing body responsible for these issues, the Department for Environment, Food and Rural Affairs (Defra) is the lead government department in England for overseeing the use of GMOs and for protecting the environment more generally. ${ }^{46}$ As for the legislation in England and Wales that governs GMOs and that implements EU law, the Environmental Protection Act 1990 is the

${ }^{43}$ Council Decision (EU) 2019/1904 of 8 November 2019 requesting the Commission to submit a study in light of the Court of Justice's judgment in Case C528/16 regarding the status of novel genomic techniques under Union law, and a proposal, if appropriate in view of the outcomes of the study.

${ }^{44}$ Defra. The regulation of genetic technologies: A public consultation on the regulation of genetic technologies. January 2021.

https://consult.defra.gov.uk/agri-food-chain-

directorate/the-regulation-of-genetic-

technologies/supporting documents/20210106\%20G ene\%20editing\%20consultation\%20document $\% 20 \mathrm{FI}$ NAL.pdf accessed 29 March 2021.

${ }^{45}$ Idem: 5.

46 Defra. About us. https://www.gov.uk/government/organisations/depart ment-for-environment-food-rural-affairs/about accessed 29 March 2021. primary piece of legislation addressing GMOs. ${ }^{47}$ It empowers the Secretary of State with the authority and responsibility to control the deliberate release of GMOs in England. ${ }^{48}$

Moreover, in line with the EU definition of GMOs, Part IV, section 6 of the Environmental Protection Act 1990 defines an organism as genetically modified if:

(4) ... any of the genes or other genetic material in the organism-

[F4 (a) have been artificially modified, or]

(b) are inherited or otherwise derived, through any number of replications, from genes or other genetic material (from any source) which were so modified.

[F5 (4A) Genes or other genetic material in an organism are "artificially modified" for the purposes of subsection (4) above if they are altered otherwise than by a process which occurs naturally in mating or natural recombination. ${ }^{49}$

Then, in accordance with the main EU directive regulating the release of GMOs across Member States in Directive 2001/18, the UK implemented this legislation in the Genetically Modified (Deliberate Release) Regulations $2002 .{ }^{50}$ Additionally, there is an extensive set of regulations on the use and labeling of GMOs in food, primarily based upon EU law. The EU Regulations governing the use of GMOs in food products across Member States in Regulations $1829 / 2003$ and 1830/2003 are implemented in England by the Genetically Modified Food (England) Regulations 2004, the Genetically Modified Animal Feed (England) Regulations, and the Genetically Modified Organisms

\footnotetext{
${ }^{47}$ Environmental Protection Act 1990.

${ }^{48}$ Ibidem.

${ }^{49}$ Environmental Protection Act, Part IV, section 6.

50 Genetically Modified (Deliberate Release) Regulations 2002.
} 
(Traceability and Labelling) (England) Regulation.

Post-Brexit, however, the regulatory framework on GMOs seems set to change and has been questioned as to its suitability in the context of gene edited organisms. Defra has already stated that it is of the view that gene edited organisms should not be regulated as GMOs if they could have been produced by traditional breeding methods. ${ }^{51}$ Seeing Brexit as an opportunity to consult on the wider implications of this issue, Defra's consultation is therefore an invitation to relevant stakeholders to share their views on the path forward. ${ }^{52}$

\section{The less restrictive approach to regulat- ing biotech}

This path forward could take the form of a less restrictive approach to the regulation of gene edited organisms. In this respect, it is useful to consider jurisdictions in which such an approach is implemented.

\section{United States}

The US leads the world in developing and commercialising GM crops, with a $30 \%$ global market share in agricultural biotechnology. ${ }^{53}$ However, unlike most other countries, the US has no federal law that regulates GMOs. ${ }^{54}$ Instead, a mechanism is in place whereby newly developed GM products are directed to

${ }^{51}$ Defra, The regulation of genetic technologies, $o p$ cit.

${ }^{52}$ Ibidem.

${ }^{53}$ Report Linker. Global Agricultural Biotechnology Industry: Global Agricultural Biotechnology Market to Reach US $\$ 66.2$ Billion by the Year 2027. July $2020 . \quad$ https://www.prnewswire.com/newsreleases/globalagricultural-biotechnology-industry301092902.html accessed 29 March 2021.

${ }^{54}$ Yang T, Chen B. Governing GMOs in the USA: science, law and public health. Journal of the Science of Food and Agriculture 2016, 96: 6. regulatory bodies under the Coordinated Framework for Regulation of Biotechnology. ${ }^{55}$ As a result, GM products are assessed within the same framework used for conventional products and under the same health, safety and environmental legislation. ${ }^{56}$ This means that the assessment of new GM crops can involve many different laws and agencies, including the Food and Drug Administration (FDA), the Environmental Protection Agency (EPA) and the US Department of Agriculture (USDA). ${ }^{57}$ In particular, the USDA's Animal and Plant Health Inspection Service (APHIS) is empowered to ensure that GM plants will not be a pest risk to other plants. ${ }^{58}$ APHIS then designates these plants as being of either regulated or nonregulated status - the latter status ensuring that the plant may be cultivated, imported and transported without regulatory oversight by APHIS. ${ }^{59}$ If the GM plant is intended for consumption, the FDA will then take over to assess the safety of the GM food product. ${ }^{60}$

${ }^{55}$ Kingsbury D. Regulation of biotechnology in the United States: One and a half years of using the 'coordinated framework'. Trends in ecology \& evolution 1988. 3: 4.

56 Matthews K. Continuing Evolution of the Coordinated Framework: Implications for Agricultural Biotechnology. In American Chemical Society. Navigating Legal Challenges in the Agrochemical Industry. ACS Publications, 2020.

${ }^{57}$ Paoletti C, et al. GMO risk assessment around the world: some examples. Trends in Food Science \& Technology 2008: 19.

${ }^{58}$ McHughen A and Smyth S. US regulatory system for genetically modified [genetically modified organism (GMO), rDNA or transgenic] crop cultivars. Plant Biotechnology Journal 2006, 6: 1.

${ }^{59}$ Nelson G (ed). Genetically Modified Organisms in Agriculture. Elsevier, 2001: 97-116.

${ }^{60}$ Dudek C. 12 GMO Food Regulatory Frameworks in the US and the EU. In Henderson K (ed). The New and Changing Transatlanticism: Politics and Policy Perspectives. Routledge, 2015: 214. 
There are currently $128 \mathrm{GM}$ plant varieties that have non-regulated status because they do not contain foreign DNA originating from 'plant pests', such as bacteria, viruses and insects. ${ }^{61}$ Similarly, when it comes to CRISPR/Cas9modified food crops, a common button mushroom was found in 2016 to resist browning and spoilage, and accordingly, was granted nonregulated status. ${ }^{62}$ From that point onwards, several other gene edited food products have entered the market: such as Calyno, a high oleic soybean oil and SU (sulfonylurea) Canola, a herbicide tolerant canola. ${ }^{63}$

It seems unlikely that the UK would adopt the US approach of handing over regulatory oversight to agencies and the general patchwork of legislation on health, safety and the environment. Yet the US approach of designating some GM plants as being of nonregulated status may encourage greater scientific developments and in conjunction with the safety checks on plants intended for consumption, may be a viable option. However, the UK should be aware that the US approach remains open for criticism because APHIS only checks GM plants for their potential as pest risks, and not for other kinds of risks, such as risks that do not stem from plant pests or risks that may harm humans and not just the environment. As such, it is advisable that the Defra consultation take into

61 USDA APHIS. Petitions for Determination of Nonregulated Status. https://www.aphis.usda.gov/aphis/ourfocus/biotechno logy/permits-notifications-petitions/petitions/petitionstatus accessed 29 March 2021.

${ }^{62}$ Waltz E. Gene-edited CRISPR mushroom escapes US regulation. Nature News 2016, 532: 7599.

63 USDA APHIS. Regulated Article Letters of Inquiry.

https://www.aphis.usda.gov/aphis/ourfocus/biotechno

logy/am-i-

regulated/Regulated_Article_Letters_of_Inquiry

accessed 29 March 2021. account a wider conception of risks than is currently the case in the US via APHIS.

\section{Canada}

As one of the top five largest biotech crop cultivators, Canada contributes $6.6 \%$ of the total worldwide biotech crop area in $2018 .{ }^{64}$ Notably, Canada follows the product-oriented approach in their regulatory framework, which has been held up by some as fostering greater innovation in agricultural biotechnology. ${ }^{65}$ What is unique about Canada's legislation in comparison to other product-based regulatory frameworks is the emphasis on the mere presence of a novel characteristic, and not the way it was modified. ${ }^{66}$ In this way, the same risk assessment mechanism carried out by the Canadian Food Inspection Agency is applied to all novel plant products regardless of whether the novel characteristic was introduced via traditional breeding methods, traditional mutagenesis, or directed mutagenesis. ${ }^{67}$

Against this background, Smyth has argued that Canada's regulatory framework has allowed it to take a strictly science-based assessment of risks related to novel plants, focusing in particular on the potential allergens, toxicity, and other unexpected impacts the plant

64 ISAAA. Global Status of Commercialized Biotech/GM Crops in 2018: Executive Brief. 2018. https://www.isaaa.org/resources/publications/briefs/5 4/executivesummary/default.asp\#: :text=On\%20the \%2023rd\%20year\%20of,189.8\%20million\%20hectar es\%20in\%202017 accessed 29 March 2021.

65 Atanassova A, Keiper F. Plant breeding innovation: a global regulatory perspective. Cereal Chemistry 2018: 95.

${ }^{66}$ Smyth S, op cit.

${ }_{67}$ CFIA. Plants with novel traits. https://www.inspection.gc.ca/plant-varieties/plantswith-noveltraits/eng/1300137887237/1300137939635 accessed 29 March 2021. 
may contain. ${ }^{68}$ The trigger for the regulations is when a plant exhibits a particular characteristic that is at least $20-30 \%$ lower or higher compared to traditional varieties. ${ }^{69}$ At this stage, the plant is designated as a plant with novel traits (PNT) and not a 'GMO'. ${ }^{70}$ Commercialisation may only occur with the approval of the Canadian Food Inspection Agency (CFIA). ${ }^{71}$ Moreover, plant products intended as food must pass an additional assessment by Health Canada and an assessment of feed will be undertaken by the Animal Feed Division of the CFIA. ${ }^{72}$

For the UK to adopt a Canadian approach would require a complete overhaul of the current regulations from the process-based approach to a product-based approach. Yet it is notable that the Canadian mechanism for assessing the safety of novel plant products does not simply 'take the scientists' word for it' that the product will have no harmful impacts. Accordingly, the accusations of UK anti-GMO NGOs that this extreme lowering of standards and oversight need not be true so long as the risk assessment of novel plants does indeed cover the allergens, toxicity and the other risks that may develop as a result of gene edited or gene modified food. ${ }^{73}$

\footnotetext{
${ }^{68}$ Smyth, op cit.

${ }^{69}$ Smyth S. Regulation of genome editing in plant biotechnology: Canada. In: Dederer H, Hamburger H (eds). Regulation of Genome Editing in Plant Biotechnology. Springer, 2019:111-135.

${ }^{70}$ CFIA, op cit.

${ }^{71}$ Turnbull, op cit.: 6.

72 Government of Canada. Novel Feeds. https://www.inspection.gc.ca/animal-

health/livestock-feeds/novel-

feeds/eng/1370227088259/1370227136675 accessed 29 March 2021.

${ }^{73}$ Jiang L. Commercialization of the gene-edited crop and morality: challenges from the liberal patent law and the strict GMO law in the EU. New Genetics and Society 2020, 39: 2.
}

\section{Impact of Defra consultation on future UK law}

\section{First part of Defra consultation}

The two-part Defra consultation was carried out under promises made under the Agricultural Bill in 2020. ${ }^{74}$ In this respect, as Peter Mills from the Nuffield Council on Bioethics notes, 'the indecent haste after the end of the Brexit transitional period, hiving off a class of applications as a potential 'quick win' and a short, ten-week consultation period betoken a political exigency to find some tangible good that might come from Brexit' ${ }^{75}$ While this raises the issue that the consultation may be overshadowed by political concerns and may fail to be objective, the consultation is nonetheless carried out in line with the standard model of government written consultations aiming to consolidate views of stakeholders, while also promoting wider discussion of the relevant issues.

The Defra consultation will first seek to gather views on the potential for the UK to stop gene editing organisms from being subject to the same strict regulation as GMOs, as long as they could have been produced naturally or via traditional breeding methods. ${ }^{76}$ In this way, the UK's legislation would be in line with the approach taken by an increasing number of

${ }^{74}$ Foote N. UK gene editing amendment withdrawn, but government commits to consultation. Euractiv 2020. https://www.euractiv.com/section/agriculturefood/news/uk-gene-editing-amendment-withdrawnbut-government-commits-to-consultation/ accessed 29 March 2021.

${ }^{75}$ Mills P. The regulation of genetic technologies: time for dialogue. Nuffield Council on Bioethics 2021. https://www.nuffieldbioethics.org/blog/theregulation-of-genetic-technologies accessed 29 March 2021.

${ }^{76}$ Defra. The regulation of genetic technologies. $O P$ cit. 
countries, such as Australia and Japan. ${ }^{77}$ Indeed, several other European countries, as well as the European Commission's own group of scientific advisors are of the same view that gene edited organisms should be regulated with a lighter touch. $^{78}$

Yet in addition to gene editing, the consultation also aims to be the start of a longerterm project seeking to collect evidence and best practice on updating the UK's approach to genetic modification. ${ }^{79}$ Consulting with key stakeholders, such as the food and farming sectors, academia, and environmental groups forms the beginning of a process that may, therefore, depending on the result, require new primary UK legislation to be drawn up, scrutinised and approved by Parliament. ${ }^{80}$

\section{Second part of Defra consultation}

The second half of the Defra consultation centres on the broader framework of GMOs. ${ }^{81}$ It is important to note that the consultation does not aim to put into place immediate changes, and instead seeks to gather information on how Defra can best reform its approach to new gene edited organisms in future. ${ }^{82}$ Moreover, it considers the effectiveness of current non-GM regulations that regulate GMOs in relation to specific sectors, such as in medicines, human food, farmed animals, crop plants. ${ }^{83}$

However, there are valid concerns that the narrow focus of the consultation on the organisms per se demonstrates that product

77 Defra. A public consultation on the regulation of genetic technologies. Op cit.: 5.

${ }_{78}^{78}$ Mills, op cit.

${ }^{79}$ Ibidem.

${ }^{80}$ Defra. The regulation of genetic technologies. $O p$ cit:: 6.

${ }^{81}$ Ibidem.

${ }^{82}$ Idem: 7.

${ }^{83}$ Idem: 5 safety is the main factor driving the discussion. ${ }^{84}$ Indeed, the consultation refers explicitly to factors such as 'impacts on trade, consumer choice, [and] intellectual property'. ${ }^{85}$ Yet the Nuffield Council of Bioethics has pointed out that there are many other interdependent elements that are involved in the discussion on gene edited organisms, including animal health, nutrition, zoonotic disease, ecosystems, biodiversity, climate, rural livelihoods, supply chains, industry structure and food security. ${ }^{86}$ Moreover, these general considerations will be relevant whether or not the biotechnologies in question produce organisms that develop as a result of 'traditional' breeding or not. ${ }^{87}$ Therefore, it seems that the terms of the consultation may have been drawn up too narrowly and it is suggested that in evaluating the outcome, Defra should acknowledge any gaps in the responses received in relation to these broader considerations.

\section{Responses to Defra consultation}

So far, the responses to the Defra consultation so far have been split between the pro-biotech scientists and the anti-GM organisations. While the former have been accused of using the consultation as an opportunity to push for more lax regulation in applications of gene editing, the latter seem to have drawn up their responses against the background of negative public attitudes towards UK agricultural biotechnology.

\section{Responses against the deregulation of gene editing}

Indeed, the anti-GM NGOs have emphasised several issues with the consultation.

\footnotetext{
${ }^{84}$ Ibidem.

${ }^{85}$ Ibidem.

${ }^{86}$ Ibidem.

${ }^{87}$ Ibidem.
} 
Foremost amongst them are the dangers, GM Freeze sees it, of moving from a product- to a process-based approach to the regulation of gene edited and gene modified organisms. ${ }^{88}$ As highlighted in their guide on responding to the consultation, 'Any unexpected effects, such as new allergens or toxins, may go unnoticed. This is not safe or sensible'. ${ }^{89}$ Additionally, as GM Freeze has stated, in collaboration with Beyond GM, GM Watch, Logos Environmental and EcoNexus, another concern relates to how the consultation focuses on so-called 'technofixes' to the exclusion of systemic change. ${ }^{90}$ As these anti-GMO NGOs explain, while they accept the consultation's premise that the UK's food system has to change, they argue that the changes needed involve the "widespread adoption of agroecological farming systems, a massive reduction in food waste, and food sovereignty, which gives people around the world control over their own food supply'. ${ }^{91}$ They contrast this with gene editing, which makes big promises to improve crop yields, tackle climate change, strengthen biodiversity, and improve the UK economy, but that rely on the assumption that complex social, political and economic issues stem from plant and animal breeding and that these can somehow be 'fixed' by 'tweaking' the genes of living organisms. ${ }^{92}$ These NGOs highlight that the agricultural problems the UK

88 GM Freeze. GM Freeze response to Defra Consultation on the Regulation of Genetic Technologies. $17 \quad$ March 2021. https://www.gmfreeze.org/wpcontent/uploads/2021/03/GM-Freeze-response-to-

Defra-Consultation-on-the-Regulation-of-Genetic-

Technologies.pdf accessed 29 March 2021.

${ }^{89}$ GM Freeze. GM Freeze advice on responding to the UK consultation on the deregulation of gene editing. Op cit.: 6.

${ }^{90}$ Ibidem.

${ }^{91}$ Ibidem.

${ }^{92}$ Ibidem. faces are more complex and deep-rooted than that, and that it would therefore be unwise to place too much hope on 'short-term technofixes' which only impede long-lasting systemic change. ${ }^{93}$

Besides these concerns relating to human health and short-term agricultural fixes, other criticisms surrounding the consultation centre on animal welfare. Against the background of gene editing being perceived by some mainstream news outlets as 'playing God', some have pointed to the harm that may be caused to animals by the possible deregulation of gene editing. As Dr Julia Baines, Science Policy Manager at PETA, stated:

'We have no business meddling with the lives of other animals, who don't consent to our tampering with their genomes to increase their profitability. Pigs, cows, and chickens are intelligent, sensitive, social beings who have their own lives, feelings, and desires and don't exist for humans to use....'Editing animals' genes won't solve world hunger - as a global switch to vegan eating could - and it will lead to misery for animals'. ${ }^{94}$

Similarly, Dr Penny Hawkins, head of the RSPCA's Animals in Science team, predicts that lowering oversight over gene editing would be a step backwards for animal welfare.

'We have real concerns about gene editing and the animal welfare issues involved. The impact of these changes to the

\footnotetext{
${ }^{93}$ Ibidem.

${ }^{94}$ Pinkstone J. UK government is set to lift the ban on controversial gene editing in agriculture so crops and livestock can be engineered to boost yields and protect them against disease. Daily Mail 2021. https://www.dailymail.co.uk/sciencetech/article9368255/UK-government-set-lift-ban-controversialgene-editing-agriculture.html accessed 29 March 2021.
} 
genome is very unpredictable and there are so many unknowns about the long-term impacts of alterations to the animals' genetic material, so there is a real risk of welfare problems being passed down the generations. We are incredibly worried that the Government is considering relaxing the rules around these procedures and, shockingly, this would also see farm animals categorised with and only given the same level of consideration as farmed crops' ${ }^{95}$

In addition to this, and with respect to the role of regulations in providing essential safeguards to human and animal health, criticism has been raised regarding the potential loss of transparency and the removal of essential protections from the deregulation of gene editing. ${ }^{96}$ Accusations that the UK government is seeking to 'obscure' where food comes from and how it was produced are voiced alongside skepticism regarding the risk of new technologies being given 'free rein' within the food system. ${ }^{97}$

Some scientists have also expressed caution in the deregulation of gene edited and gene modified organisms. In 2017 a statement published by the European Network of Scientists for Social and Environmental Responsibility (ENSSER) was signed by scientists worldwide. One of its recommendations was that, 'due to our lack of knowledge and the possibility of unintended errors, the products of new genetic modification techniques should be strictly regulated as GMOs'. ${ }^{98}$

\footnotetext{
${ }^{95}$ Ibidem.

${ }^{96}$ GM Freeze. GM Freeze advice on responding to the UK consultation on the deregulation of gene editing. Op cit.: 6.

${ }^{97}$ Ibidem.

${ }^{98}$ European Network of Scientists for Social and Environmental Responsibility. ENSSER Statement
}

\section{Responses in favour of the deregulation of gene editing}

However, the pro-biotech lobbyists insist that gene editing could improve the agriculture and aquaculture system and could help feed a growing population. As the UK Environment Secretary, George Eustice, said:

'Gene editing has the ability to harness the genetic resources that mother nature has provided, in order to tackle the challenges of our age. This includes breeding crops that perform better, reducing costs to farmers and impacts on the environment, and helping us all adapt to the challenges of climate change. Its potential was blocked by a European Court of Justice ruling in 2018, which is flawed and stifling to scientific progress. Now that we have left the EU, we are free to make coherent policy decisions based on science and evidence. That begins with this consultation'. ${ }^{99}$

Farmers and scientists tend to be in favour of removing these so-called blocks to progress. As Tom Bradshaw, vice president of the National Farmers Union, argued: 'Gene editing has the potential to offer huge benefits to UK farming and the environment. It could help us address pest and disease pressures on our crops and livestock, increasing our resilience in the event of extreme weather events'. ${ }^{100}$

Others in the agricultural sector agree. The Agricultural Industries Confederation (AIC) has responded warmly to the Defra consultation.

on New Genetic Modification Techniques 2017. https://ensser.org/publications/ngmt-statement accessed 29 March 2021.

${ }^{99}$ Byrne J. UK feed and pig industries welcome UK consultation on gene editing. Feed Navigator 2021. https://www.feednavigator.com/Article/2021/01/07/U K-feed-and-pig-industries-welcome-UKconsultation-on-gene-editing accessed 29 March 2021.

${ }^{100}$ Pinkstone, op cit. 
Robert Sheasby, CEO of the AIC, repesenting the voices of the UK feed and agri-supply sector, announced that:

'The AIC warmly welcomes the launch of this government consultation on gene editing in crops and livestock. We have long sought to support sustainable modern commercial agriculture in the UK, and this is the opportunity for our members to put forward their views on this development. We would encourage the industry at large to respond'. ${ }^{101}$

Similarly, a number of UK governmental departments have responded positively to the possibility that the consultation could lead to a change in legislation. Professor Robin May, chief scientific officer of the UK's Food Standards Agency (FSA), welcomed the consultation, stating that:

'The UK prides itself in having the very highest standards of food safety, and there are strict controls on GM crops, seeds and food which the FSA will continue to apply moving forward. As with all novel foods, GE foods will only be permitted to be marketed if they are judged to not present a risk to health, not to mislead consumers, and not have lower nutritional value than existing equivalent foods. We will continue to put the consumer first and be transparent and open in our decision-making. Any possible change would be based on an appropriate risk assessment that looks at the best available science' ${ }^{102}$

Indeed, such changes have been increasingly anticipated in light of the 2020 Nobel Prize in Chemistry being awarded to Emmanuelle Charpentier and Jennifer A. Doudna 'for the development of a method for genome editing' in the form of CRISPR-Cas9

\footnotetext{
${ }^{101}$ Ibidem.

102 Byrne, op cit.
}

gene editing. ${ }^{103}$ In this light, Sir David Baulcombe, professor of botany in the Department of Plant Sciences at the University of Cambridge, pointed out that the overwhelming view of public sector scientists is that these Nobel prize winning methods for gene editing can lead to better availability of crops and livestock as part of a sustainable and profitable agricultural system. ${ }^{104}$

One such public sector scientists point to the potential for improvement of animal welfare following the lifting of restrictions on gene editing. As Prof Mick Watson, Personal Chair of Bioinformatics and Computational Biology, Roslin Institute, University of Edinburgh, stated:

'Not only does the information in their genes control how animals grow, it also provides routes for pathogens such as viruses to enter animal cells and cause disease. Scientists at The Roslin Institute, and elsewhere in the world, have identified genes, or loci, within animal genomes that confer both susceptibility and resistance to a range of diseases, and we have demonstrated the power of gene editing by creating pigs that are resistant to Porcine Reproductive and Respiratory Syndrome, a devastating viral disease.

As well as improving animals' ability to respond to disease, gene editing could also be used to create fitter, healthier animals with higher standards of animal welfare. I welcome this initiative from Defra which

103 Ryan Cross, 'CRISPR genome editing gets 2020 Nobel Prize in Chemistry' ( $C \& E N, 9$ October 2020) https://cen.acs.org/biological-chemistry/geneediting/CRISPR-genome-editing-2020-Nobel/98/i39 accessed 29 March 2021.

${ }^{104}$ Byrne, op cit. 
could place cutting-edge technology at the heart of UK livestock improvement'. ${ }^{105}$

The diverse range of views that have been put forward during this consultation will be considered by Defra and published in a few months' time. At the moment, since Defra itself seems to be staunchly in favour of a relaxation of the rules on gene edited organisms within the agriculture and aquaculture system, these scientists' and farmers' positive responses to the consultation seem to strengthen Defra's resolve to push through new legislation.

\section{IV.Suggestions for Defra consultation results}

While the outcome seems set to provide more support to a new regulatory framework in the UK, perhaps along the lines of the US or Canada's less restrictive approach to biotech, it is still important that several key considerations aiming to balance competing interests are used in assessing the outcome. Some proposed considerations include:

1. All forms of gene editing should be subject to robust, but possibly differing levels of, regulation and risk assessments.

2. The consultation should operate against the background of a greater recognition of the whole host of other approaches to ensuring a sustainable and healthy food system, including organic and other agroecological farming.

3. Whether or not GM assessments are retained, it may be useful to extend the assessments to include social, ethical and values-based criteria.

4. Genetic engineering legislation should take into account a consideration of the alterna-

${ }^{105}$ Science Media Centre. Expert reaction to Defra consultation on gene editing. 2021. https://www.sciencemediacentre.org/expert-reactionto-defra-consultation-on-gene-editing/ accessed 29 March 2021. tives, including traditional alternatives, and require a detailed and independently assessed. justification of the social and environmental need for the proposed new organism

5. Long-term safety assessments should be carried out that consider all unintended effects.

6. Post-release monitoring of gene-edited or modified organisms should be prioritised.

7. Consumer labeling should be as clear as possible so as to support and educate consumer choice.

8. Should gene edited food be made available on the market, public awareness of the difference between gene edited and modified food products could be raised through information campaigns to empower consumers to make their own decisions about the food they purchase and consume.

Besides all these suggestions, it is important that the developments in legislation on GM and GE products across jurisdictions around the world continue to be monitored. While a short summary of the legal framework in several countries has been provided in previous sections, the growing acceptance of governments of the need to foster scientific advancements in GM and GE means that there may soon be more countries - and not just the UK - that will look to the US and Canada as prime examples of less restrictive regulatory systems.

\section{Conclusion}

Ultimately, any consideration of changes to UK legislation that allow gene edited agricultural and aquacultural products to enter into the market and to be further developed by scientists must operate within a broader framework of the challenges facing the UK food and farming system. Regardless of the outcome of the Defra consultation, its role in raising awareness of the relevance of gene editing is hugely important. Informed debate on the complex societal, ethical, animal, economic, and environmental issues associated with gene edited products will help to shape future national policy as a new generation of biotechnologies is developed and will help to direct the 
development of the UK's future food and farming system.

\section{Bibliography}

1. UK Department for the Environment, Food and Rural Affairs. The regulation of genetic technologies. 2021. https://consult.defra.gov.uk/agri-foodchain-directorate/the-regulation-ofgenetic-technologies/ accessed 29 March 2021.

2.UK Department for the Environment, Food and Rural Affairs. Gene editing: explainer. 2021. https://consult.defra.gov.uk/agri-foodchain-directorate/the-regulation-ofgenetictechnologies/supporting documents/Gen e\%20Editing\%20Explainer.pdf accessed 29 March 2021.

3. Sandercock H. Defra launches consultation on crop gene editing plans. The Grocer 2021. https://www.thegrocer.co.uk/fruitand-veg/defra-launches-consultation-oncrop-gene-editing-plans/651858.article accessed 29 March 2021.

4. Marshall C. Consultation launched over gene edited food in England. BBC 2021. https://www.bbc.com/news/scienceenvironment-55576187 accessed 29 March 2021.

5. Turnbull C, et al. Global Regulation of Genetically Modified Crops Amid the Gene Edited Crop Boom - A Review. Frontiers in Plant Science 2021: 12.

6. International Service for the Acquisition of Agri-biotech Applications (ISAAA). GM Approval Database http://www.isaaa.org/gmapprovaldatabas e/default.asp accessed 29 March 2021.

7. Sprink $T$, et al. Regulatory hurdles for genome editing: process-vs. productbased approaches in different regulatory contexts. Plant Cell Reports 2016, 35: 7.

8.GM Freeze. GM Freeze advice on responding to the UK consultation on the deregulation of gene editing. January 2021. https://www.gmfreeze.org/wpcontent/uploads/2021/01/GMF-Gene-
Editing-Consultation-1-2.pdf accessed 29 March 2021.

9. Ellens $\mathrm{K}$, et al. Canadian regulatory aspects of gene editing technologies. Transgenic Research 2019, 28: 2.

10. Eckerstorfer MF, Engelhard M, Heissenberger A, Simon S, and Teichmann H. Plants developed by new genetic modification techniques comparison of existing regulatory frameworks in the EU and Non-EU countries. Frontiers of Bioengineering and Biotechnology 2018, 7: 26.

11. McHughen A. A critical assessment of regulatory triggers for products of biotechnology: product vs. process. GM Crops Food 2016: 7.

12. Lombardo L, Grando MS. Genetically modified plants for nutritionally improved food: a promise kept? Food Reviews International 2020: 36.

13. Marchant GE, Stevens YA. A new window of opportunity to reject processbased biotechnology regulation. GM Crops Food 2015: 6.

14. Bendiek J, Buhk H. Risk Assessment and Economic Applications - the Cartagena Protocol on Biosafety: GMO Approval and Import on a World-Wide Scale. In: F Kempken, C Jung (eds). Genetic Modification of Plants. Springer, 2010: 631.

15. Wasmer M. Roads forward for European GMO policy-uncertainties in wake of ECJ judgment have to be mitigated by regulatory reform. Frontiers of Bioengineering and Biotechnology 2019, 7: 132.

16. Eriksson D, Custers R, Edvardsson Björnberg K, Hansson SO, Purnhagen K, Qaim M. Options to reform the European Union legislation on GMOs: scope and definitions. Trends in Biotechnology 2020, 38: 231-234.

17. Wanner B, Monconduit H, Mertens A, and Thomaier J. CJEU renders decision on the interpretation of the GMO Directive. Journal of Intellectual Property Law and Practice 2019: 14. 
18. Smyth S. Canadian regulatory perspectives on genome engineered crops' GM Crops \& Food 2017, 8: 1.

19. Defra. The regulation of genetic technologies: A public consultation on the regulation of genetic technologies. January 2021. https://consult.defra.gov.uk/agri-foodchain-directorate/the-regulation-ofgenetictechnologies/supporting_documents/2021 0106\%20Gene\%20editing\%20consultatio n\%20document\%20FINAL.pdf accessed 29 March 2021.Defra. The regulation of genetic technologies: A public consultation on the regulation of genetic technologies. January 2021. https://consult.defra.gov.uk/agri-foodchain-directorate/the-regulation-ofgenetictechnologies/supporting_documents/2021 0106\%20Gene\%20editing\%20consultatio n\%20document\%20FINAL.pdf accessed 29 March 2021.

20. Defra.

About

us. https://www.gov.uk/government/organisa tions/department-for-environment-foodrural-affairs/about accessed 29 March 2021.

21. Report Linker. Global Agricultural Biotechnology Industry: Global Agricultural Biotechnology Market to Reach US\$66.2 Billion by the Year 2027. July 2020. https://www.prnewswire.com/newsreleases/globalagriculturalbiotechnology-industry-301092902.html accessed 29 March 2021.

22. Yang T, Chen B. Governing GMOs in the USA: science, law and public health. Journal of the Science of Food and Agriculture 2016, 96: 6.

23. Matthews K. Continuing Evolution of the Coordinated Framework: Implications for Agricultural Biotechnology. In American Chemical Society. Navigating Legal Challenges in the Agrochemical Industry. ACS Publications, 2020.
24. Paoletti C, et al. GMO risk assessment around the world: some examples. Trends in Food Science \& Technology 2008: 19.

25. McHughen A, Smyth S. US regulatory system for genetically modified [genetically modified organism (GMO), rDNA or transgenic] crop cultivars. Plant Biotechnology Journal 2006, 6: 1.

26. Dudek C. 12 GMO Food Regulatory Frameworks in the US and the EU. In Henderson K (ed). The New and Changing Transatlanticism: Politics and Policy Perspectives. Routledge, 2015: 214.

27. USDA APHIS. Petitions for Determination of Nonregulated Status. https://www.aphis.usda.gov/aphis/ourfoc us/biotechnology/permits-notificationspetitions/petitions/petition-status accessed 29 March 2021.

28. ISAAA, Global Status of Commercialized Biotech/GM Crops in 2018: Executive Brief. 2018. https://www.isaaa.org/resources/publicati ons/briefs/54/executivesummary/default. asp\#: : text=On\%20the $\% 2023 \mathrm{rd} \% 20$ year \%20of,189.8\%20million\%20hectares\%2 0in\%202017 accessed 29 March 2021.

29. Atanassova A, Keiper F. Plant breeding innovation: a global regulatory perspective. Cereal Chemistry 2018: 95.

30. CFIA. Plants with novel traits. https://www.inspection.gc.ca/plantvarieties/plants-with-noveltraits/eng/1300137887237/130013793963 $\underline{5}$ accessed 29 March 2021.

31. Smyth S. Regulation of genome editing in plant biotechnology: Canada. In Dederer $\mathrm{H}$ and Hamburger $\mathrm{H}$ (eds). Regulation of Genome Editing in Plant Biotechnology. Springer, 2019: 111-135.

32. Government of Canada. Novel Feeds. https://www.inspection.gc.ca/animalhealth/livestock-feeds/novelfeeds/eng/1370227088259/13702271366 75 accessed 29 March 2021.

33. Jiang L. Commercialization of the geneedited crop and morality: challenges from the liberal patent law and the strict GMO 
law in the EU. New Genetics and Society 2020, 39: 2.

34. Foote N. UK gene editing amendment withdrawn, but government commits to consultation. Euractiv 2020. https://www.euractiv.com/section/agricul ture-food/news/uk-gene-editingamendment-withdrawn-but-governmentcommits-to-consultation/ accessed 29 March 2021.

35. Mills $P$. The regulation of genetic technologies: time for dialogue. Nuffield Council on Bioethics 2021. https://www.nuffieldbioethics.org/blog/th e-regulation-of-genetic-technologies accessed 29 March 2021.

36. GM Freeze. GM Freeze response to Defra Consultation on the Regulation of Genetic Technologies. 17 March 2021. https://www.gmfreeze.org/wpcontent/uploads/2021/03/GM-Freezeresponse-to-Defra-Consultation-on-theRegulation-of-Genetic-Technologies.pdf accessed 29 March 2021.

37. Pinkstone J. UK government is set to lift the ban on controversial gene editing in agriculture so crops and livestock can be engineered to boost yields and protect them against disease. Daily Mail 2021. https://www.dailymail.co.uk/sciencetech/ article-9368255/UK-government-set-liftban-controversial-gene-editingagriculture.html accessed 29 March 2021.

38. European Network of Scientists for Social and Environmental Responsibility. ENSSER Statement on New Genetic Modification Techniques 2017. https://ensser.org/publications/ngmtstatement accessed 29 March 2021.

39. Byrne J. UK feed and pig industries welcome UK consultation on gene editing. Feed Navigator 2021. https://www.feednavigator.com/Article/2 021/01/07/UK-feed-and-pig-industrieswelcome-UK-consultation-on-geneediting accessed 29 March 2021.
40. Science Media Centre. Expert reaction to Defra consultation on gene editing. 2021. https://www.sciencemediacentre.org/expe rt-reaction-to-defra-consultation-on-geneediting/ accessed 29 March 2021. 